\title{
Atropa Belladonna L. Water Extract: Modulator of Extracellular Matrix Formation in Vitro and in Vivo
}

\author{
P. GÁL ${ }^{1,2,4}$, T. VASILENKO ${ }^{2,3}$, I. KOVÁČ ${ }^{1}$, M. KOSTELNÍKOVÁ ${ }^{1}$, J. JAKUBČO ${ }^{1}$, \\ P. SZABO ${ }^{5}$, B. DVOŘÁNKOVÁ ${ }^{5}$, F. SABOL ${ }^{6}$, H.-J. GABIUS ${ }^{7}$, K. SMETANA Jr. ${ }^{5}$
}

${ }^{1}$ Department for Biomedical Research, East-Slovak Institute of Cardiovascular Diseases, Košice, Slovak Republic, ${ }^{2}$ Department of Pathological Anatomy, University of Veterinary Medicine and Pharmacy, Košice, Slovak Republic, ${ }^{3}$ Third Clinic of Surgery, Slovak Health University and First Private Hospital Košice-Šaca, Košice, Slovak Republic, ${ }^{4}$ Institute of Histology and Embryology, and ${ }^{5}$ Institute of Anatomy, First Faculty of Medicine, Charles University, Prague, Czech Republic, ${ }^{6}$ Clinic of Heart Surgery, East-Slovak Institute of Cardiovascular Diseases, Košice, Slovak Republic, ${ }^{7}$ Institute of Physiological Chemistry, Faculty of Veterinary Medicine, LudwigMaximilian-University, Munich, Germany

Received May 5, 2011

Accepted February 16, 2012

On-line April 5, 2012

\section{Summary}

Previously, we found that treatment of cutaneous wounds with Atropa belladonna L. (AB) revealed shortened process of acute inflammation as well as increased tensile strength and collagen deposition in healing skin wounds (Gál et al. 2009). To better understand $A B$ effect on skin wound healing male SpragueDawley rats were submitted to one round full thickness skin wound on the back. In two experimental groups two different concentrations of $A B$ extract were daily applied whereas the control group remained untreated. For histological evaluation samples were removed on day 21 after surgery and stained for wide spectrum cytokeratin, collagen III, fibronectin, galectin-1, and vimentin. In addition, in the in vitro study different concentration of $A B$ extract were used to evaluate differences in HaCaT keratinocytes proliferation and differentiation by detection of Ki67 and keratin-19 expressions. Furthermore, to assess ECM formation of human dermal fibroblasts on the in vitro level fibronectin and galectin- 1 were visualized. Our study showed that $A B$ induces fibronectin and galectin-1 rich ECM formation in vitro and in vivo. In addition, the proliferation of keratinocytes was also increased. In conclusion, $A B$ is an effective modulator of skin wound healing. Nevertheless, further research is needed to find optimal therapeutic concentration and exact underlying mechanism of action.

\section{Key words}

Phytotherapy • Aqueous extract • Wound healing • Fibroblast • Keratinocyte • Inflammation

\section{Corresponding author}

Peter Gál, East-Slovak Institute of Cardiovascular Diseases, Department for Biomedical Research, Ondavská ul. č. 8, 04011 Košice, Slovak Republic. E-mail: pgal@vusch.sk or galovci@yahoo.com

\section{Introduction}

The quest for finding ways to improve wound healing warrants to test new approaches. Toward this end, experimental studies are exploring the potential for benefit, examining for example physical (Gurdol et al. 2010, Lacjakova et al. 2010, Toporcer et al. 2006, Vasilenko et al. 2010) and pharmacological methods (Chu et al. 2010, Gál et al. 2010, Novotný et al. 2011), stem cell therapy (Luo et al. 2010, Nishino et al. 2011) or phytotherapy (Priya et al. 2004, SkórkowskaTelichowska et al. 2010). Considering economic aspects, applying natural products represents a feasible option of treatment in many regions of the world. In this respect, the use of Atropa belladonna L. (AB) aqueous extract for improving skin-wound healing has a long 
tradition in the folk medicine of "Spiš region" located in the Eastern Slovakia. As often encountered, the effect of this herb has never rigorously been experimentally verified, prompting us to perform our previous investigation. We found that AB-treated wounds have a shortened process of inflammationas as well as enhanced collagen deposition and increased tensile strength when compared with their untreated controls (Gál et al. 2009). Furthermore, our in vitro study revealed that keratinocytes in the presence of $A B$ expressed keratin-19.

Poorly differentiated cells have a large potential to stimulate new tissue development and/or formation (Chen et al. 2009, Fu and Li 2009), an aspect of crucial significance for wound healing (Lau et al. 2010). Herein, several (glyco)proteins, especially components of the extracellular matrix (ECM), play important roles to facilitate cell-cell and cell-matrix interactions, what is essential for an effective course of healing (Suzuki et al. 2003, Nečas et al. 2010, Dvoŕánková et al. 2011). It has already been shown that an ECM rich in fibronectin and galectin-1 may serve as active substratum that can substitute for feeder cells in the case of keratinocytes (Dvořánková et al. 2011). In addition, galectin-1, an endogenous adhesion/growthregulatory lectin (Gabius 2006, Villalobo et al. 2006, Gabius et al. 2011) was found to be up-regulated during the early phases of healing (Klíma et al. 2009) as well as to be capable to act anti-inflammatorily (Cooper et al. 2010). Of note, both fibronectin and galectin-1 production have been detected in our in vivo and in vitro investigations. To extend the scope of study, collagen-3, keratin-19, Ki67, vimentin, and wide-spectrum keratin were investigated as well.

In principle, in order to achieve swift repair and regeneration of injured tissues it would be ideal to prime cells for optimal cell biological properties and for suitable ECM production. In our previous investigation, it was observed that $\mathrm{AB}$ has the capability to modulate these processes (Gál et al. 2009). This study was therefore designed as a combined in vivo (conducted on rats) and in vitro (conducted on keratinocytes and fibroblasts) investigation to better understand the mechanisms behind AB-dependent modulatory effects on skin wound healing. Tissue and cell specimens were processed under identical conditions to exclude any factor other than $\mathrm{AB}$ treatment to affect signal occurrence and intensity.

\section{Methods}

Plant material - Atropa belladonna L. (AB)

AB (Solanaceae) was collected in August 2006 from the vicinity of mast on Čertova sihot', Slovak Paradise, Slovak Republic. The plant was unequivocally identified by Dr. Pavol Mártonfi from the Department of Botany, Institute of Biology and Ecology, Šafárik University in Košice. Herb (overground parts) of the plant was dried at room temperature in the dark. A voucher specimen (KO-30301) was deposited in the Herbarium of the Botanical Garden of the Šafárik University in Košice.

\section{Preparation of the aqueous extract of $A B$}

The water extract for both in vitro and in vivo experiments was prepared by pouring $10 \mathrm{~g}$ of a powder of dried AB leaves into $100 \mathrm{ml}$ of boiling distilled water. The suspension was then left for 10 minutes at room temperature. Consecutively, the extract was filtered $(0.2 \mu \mathrm{m})$.

For the animal study two concentrations were used: the original solution obtained by extraction (AB$10 \%$ ) and a 10-times diluted concentration (AB-1 \%). For the in vitro study the extract was 10-times diluted in culture medium and the obtained concentration was considered to be the highest concentration (AB-1\%). In addition to this concentration tested, $\mathrm{AB}$ extract was 256 times diluted (AB-0.00390625\%). Preliminary doseresponse testing included $0.25 \%, 0.0625 \%$, and $0.015626 \%$ concentrations (unpublished data).

\section{Animal model}

The experimental conditions were in compliance with the requirements of the European rules of ethical standards of animal treatment and welfare. Hence, our experiment was approved by the Ethics Committee of the Faculty of Medicine of the Šafárik University in Košice and by the State Veterinary and Food Administration of the Slovak Republic.

Male Sprague-Dawley rats $(n=12 ; 8-10$ months of age) were used for experiments and allocated into 3 groups (control - untreated; AB-10\% - treated with the high AB concentration, AB-0.00390625\% - treated with the low $\mathrm{AB}$ concentration). For general anesthesia a combination of $33 \mathrm{mg} / \mathrm{kg}$ ketamine (Calypsol; Richter Gedeon, Budapest, Hungary), $11 \mathrm{mg} / \mathrm{kg}$ xylazine (Rometar a.u.v.; Spofa, Prague, Czech Republic) and $5 \mathrm{mg} / \mathrm{kg}$ tramadol (Tramadol-K; Krka, Novo Mesto, 
Slovenia) was intramuscularly administered to the rats. One round $-1 \mathrm{~cm}$ in diameter - full thickness skin wound was performed under aseptic conditions on the back of each rat. All rats were sacrificed by ether inhalation 21 days after surgery.

\section{Wound treatment}

During the treatment all rats were restrained individually in a Plexiglas cage with a circular opening over the wound. In the control group, the aqueous AB extract was not applied. In the experimental groups, the extract was topically applied (by means of an eye dropper) three times a day during the first three days of healing. New extract was prepared each day of wound treatment.

\section{Basic histology and immunohistochemistry}

The first half of skin-wound specimens was processed routinely for light microscopy, i.e. fixation in $4 \%$ buffered formaldehyde, dehydration, embedding, cutting, and staining with hematoxylin-eosin.

The second half of wound specimens was cryoprotected by Tissue-Tek (Sakura, Zoeterwoude, Netherlands) and deeply frozen in liquid nitrogen. Cryocut sections (Reichert-Jung, Vienna, Austria) were first mounted on the surface of poly-L-lysine-treated glasses (Sigma-Aldrich, St Louis, MO, USA), then fixed in $2 \%(\mathrm{w} / \mathrm{v})$ paraformaldehyde in phosphate-buffered saline (PBS; pH 7.2). Any binding of the used secondarystep antibody preparations was precluded by preincubation with normal swine serum (DAKO, Glostrup, Denmark) diluted in PBS for $30 \mathrm{~min}$. Both first- and second-step antibodies were diluted as recommended by supplier, the sources given in Table 1 . The specificity of immunohistochemical reactions was verified by the replacement of used antibody by an irrelevant antibody and/or by the omission of the first-step antibody. The lack of cross-reactivity of our homemade anti-galectin-1 antibody was ascertained, if required, after affinity depletion on resin with conjugated galectins (Kaltner et al. 2002, Saal et al. 2005).

The nuclei of cells were counterstained with the DAPI fluorochrome (Sigma-Aldrich, St Louis, MO, USA), specifically recognizing DNA. The specimens were mounted to Vectashield (Vector Laboratories, Burlingame, CA, USA).

\section{Wound area measurement}

The area of healing wounds was measured from standardized photographs as follows. Wounds were photographed with a scale immediately after surgery and at 21 using an Olympus E330 digital camera equipped with a digital ED $50 \mathrm{~mm}$ f 2.0 macro objective and a ring set flash SRF-11 (Olympus, Tokyo, Japan). The wound area was then measured on the images using Quick Photo Micro 2.2 software (Premiere, Prague, Czech Republic) and expressed as a percentage of the original wound area created on the day of surgery.

Isolation and in vitro cultivation of human dermal fibroblasts (HDF)

Fibroblasts were isolated from residual skin samples. They were obtained from the Department of Aesthetic Surgery of the Third Faculty of Medicine of Charles University according to the criteria of the Helsinki Declaration with informed consent of patients and approved by local Ethical Committee. Cells were cultured in Dulbecco's Modified Eagle's Medium (DMEM) (Biochrom, Berlin, Germany) supplemented with $10 \%$ fetal bovine serum (FBS; Biochrom) and antibiotics (streptomycin and penicillin; Biochrom).

Cells were seeded on glass coverslips at a density of 3000 cells $/ \mathrm{cm}^{2}$ and cultured for 24 hours. Medium containing the tested concentration of $\mathrm{AB}$ extract was then added to the cells, which were cultured thereafter for three days.

\section{In vitro cultivation of $\mathrm{HaCaT}$}

The HaCaT (human keratinocytes cell line) cell line was obtained from Cell Lines Service (Eppelheim, Germany) (Boukamp et al. 1988). Cells were cultured in the Dulbecco's Modified Eagle's Medium (DMEM; Biochrom) supplemented with $10 \%$ FBS (Biochrom) and antibiotics (streptomycin and penicillin; Biochrom).

Cells were seeded on a glass coverslips at a density of 5000 cells $/ \mathrm{cm}^{2}$ and cultured for 24 hours. Medium containing the tested concentration of $\mathrm{AB}$ extract was then added to cells, which were cultured thereafter for four days (medium was changed $1 \mathrm{x}$ during the experiment).

Immunocytochemistry of in vitro cultured keratinocytes and fibroblasts

The adherent cells on the coverslips were washed in PBS and fixed briefly with $2 \%$ (w/v) paraformaldehyde diluted in PBS $(\mathrm{pH}=7.2)$. Any binding of the used second-step antibody was precluded by preincubation with normal swine serum (DAKO, Glostrup, 

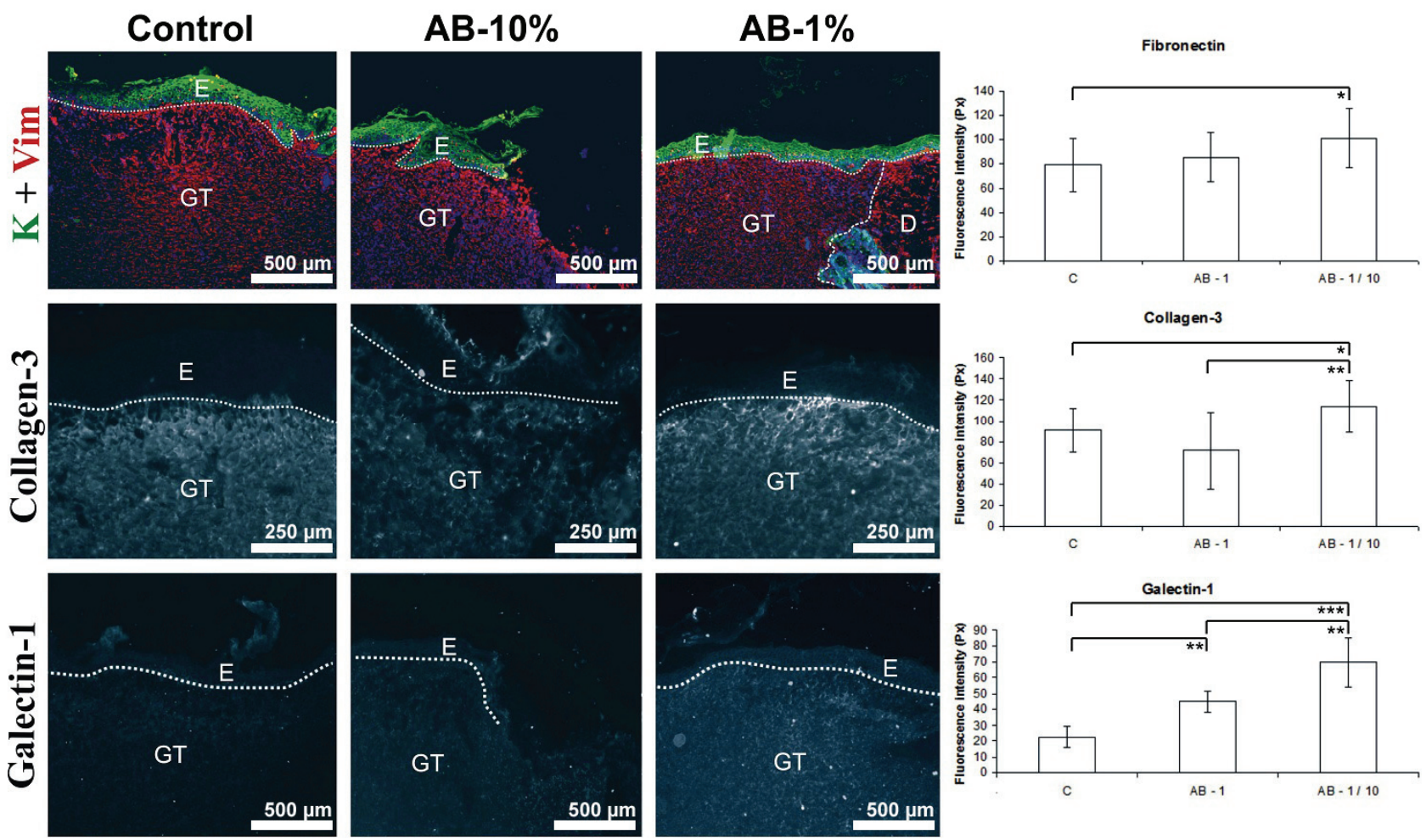

Fig. 1. Control/untreated wounds and wounds treated with two different concentrations of Atropa belladonna (AB); first vertical panel: completed process of epidermis (E) regeneration and well-formed granulation tissue (GT) rich in collagen-3, but poor in galectin-1; second vertical panel: incomplete process or re-epithelialization, granulation tissue poor in collagen-3, but increased content of galectin-1; third vertical panel: finished re-epithelialization, well-formed granulation tissue rich in collagen and galectin-1 ( $D$ - dermis); fluoresecence for fibronectin intensity is shown in the top graph, collagen-3 fluoresecence intensity in the middle graph, and galectin-1-dependent fluorescence intensity in the bottom graph ( $\mathrm{p}<0.05, * * p<0.01, * * * p<0.001)$.

Denmark) diluted in PBS for 30 min. Both the primary and secondary antibodies were diluted as recommended by supplier and are described in Table 1 . Their specificity was tested by replacement of a distinct antibody by another polyclonal or monoclonal antibody of the same animal and isotype, but against antigens not present in studied cells. The nuclei of cells were routinely counterstained with DAPI (Sigma-Aldrich). The specimens were mounted with Vectashield (Vector Laboratories).

Fluorescence intensities measurement, cell counting, and image analysis

Both skin sections and coverslips containing cultured cells were analyzed by fluorescence microscopy using a Nikon Eclipse 90i apparatus (Nikon, Tokyo, Japan) equipped with filter-blocks specific for FITC, TRITC and DAPI, respectively, a high-resolution CCD camera Cool-1300Q (Vosskühler, Osnabrück, Germany) and a LUCIA 5.1 computer-assisted image analysis system (Laboratory Imaging, Prague, Czech Republic). Fluorescence intensity was measured under standardized conditions (Klíma et al. 2009) using the software given above.

By evaluating Ki67 expression all cells were counted in three visualization field of one coverslip following by counting the Ki67 positive cells. The proliferation activity was than expressed as the percentage of Ki67 positive cells to total no. of cells.

\section{Statistical analysis}

Data from the measurement of fluorescence intensities, wound areas, and cell counting were compared by one-way ANOVA followed by TukeyKramer post-hoc test. Significance was accepted at $\mathrm{p}<0.05$.

\section{Results}

Wound histology

At the period of 21 days post surgery regeneration of the epidermis was completely finished in the control and AB-1 \% groups, but not in the AB-10\% group (Fig. 1). Only a limited number of luminized 


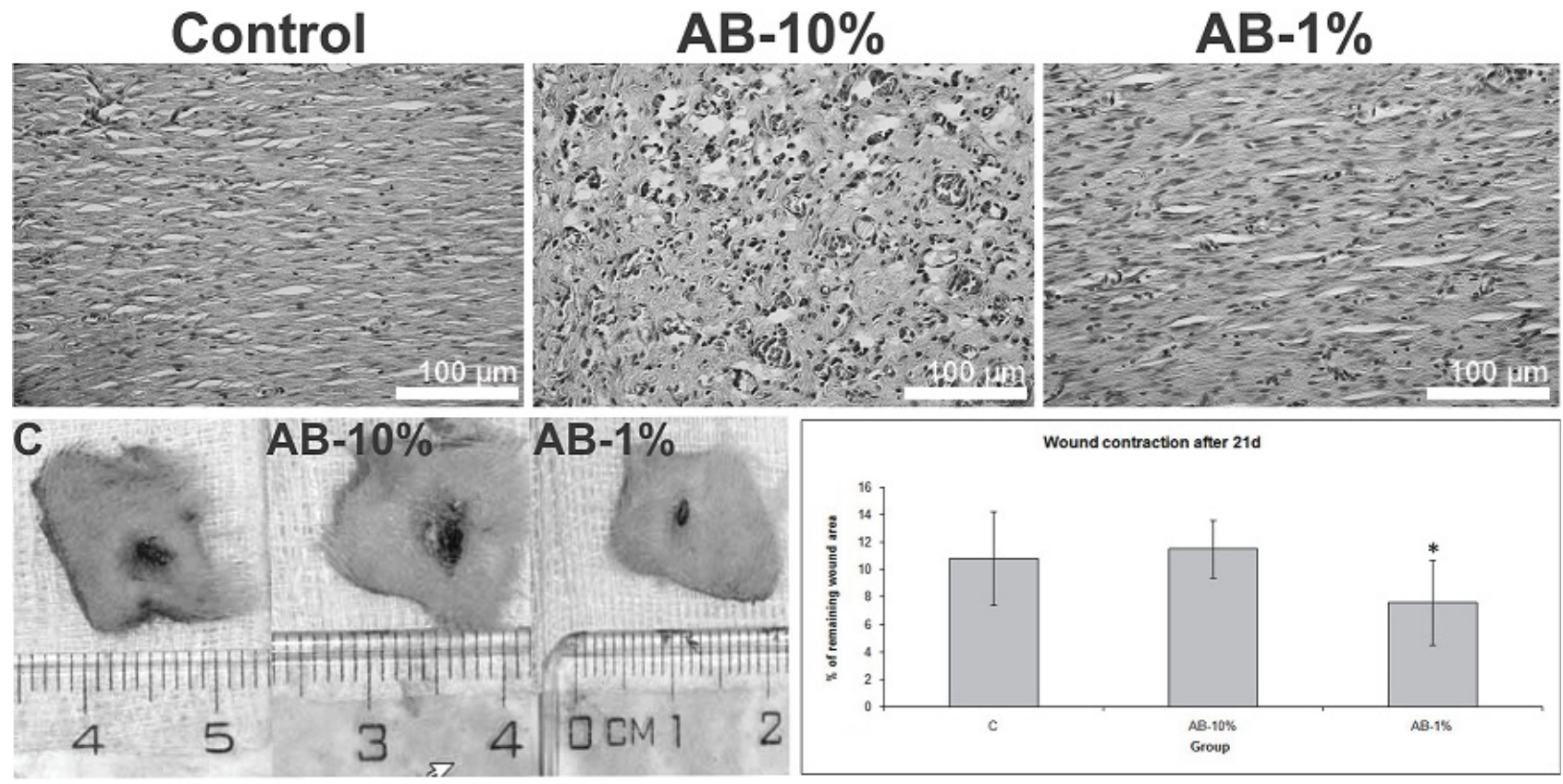

Fig. 2. Effect of Atropa belladonna water extract on granulation tissue formation (HE staining) and skin wound closure in rats. Immature granulation tissue formation with high number of luminised vessels in wounds treated with the higher tested $A B$ concentration ( $A B-10 \%)$. In contrast, control wounds showed normal process of tissue scaring. The most mature scare was observed in wounds treated with the lower tested $A B$ concentration (AB-1\%) where the extract also significantly increased wound contraction in comparison to other groups $(* p<0.05)$.

vessels was present in the granulation tissues of control and treated wounds (not shown). The level of fibronectin presence in the granulation tissue was comparable in untreated wounds (control) and wounds treated with the undiluted $\mathrm{AB}$ extract (AB-10\%) (not shown). However, treatment of wounds with the diluted AB extract (AB$1 \%$ ) resulted in significantly increased production of fibronectin (Fig. 1). Interestingly, granulation tissue of the treated wounds contained a significantly increased amount of galectin-1 when compared to the control (Fig. 1). Of note, the presence of collagen-3 was enhanced in wounds treated with the diluted $\mathrm{AB}$ extract, while high extract concentration decreased collagen deposition when compared to the other two groups (Fig. 1).

\section{Wound contraction}

Measuring the extent of wound contraction revealed significant effect of lower tested $A B$ concentration (AB-1\%) when compared to control (Fig. 2), while the higher tested AB concentration (AB$10 \%$ ) did not significantly modulated wound closure.

\section{$H D F$}

The presence of $\mathrm{AB}$ in the culture medium led to the formation of a ECM scaffold which consisted of fibronectin and galectin-1 (Fig. 2). The most prominent newly synthesized ECM network was observed on the coverslips with cells exposed to the higher tested extract concentration (AB-1\%). ECM production was then leveling off in a concentration dependent manner (AB$0.00390625 \%$ ).

The presence of $\mathrm{AB}$ in the culture medium did not stimulate any transition of fibroblasts into myofibroblasts (not shown). As consequence, no or only a very limited number (up to one per visualization field) of myofibroblasts was present.

\section{HaCaT}

All cells expressed wide-spectrum keratin. In contrast to ECM production the most prominent expression of Ki67 was observed in cells exposed to the lower tested $\mathrm{AB}$ concentrations (AB-0.00390625\%). With increasing plant concentration Ki67 expression decreased (Fig. 3). No differences were observed in keratin-19 expression between control and AB stimulated cells (not shown).

\section{Discussion}

In our previous investigation we found keratinocyte, cultured on $3 \mathrm{~T} 3$ feeder fibroblasts, 

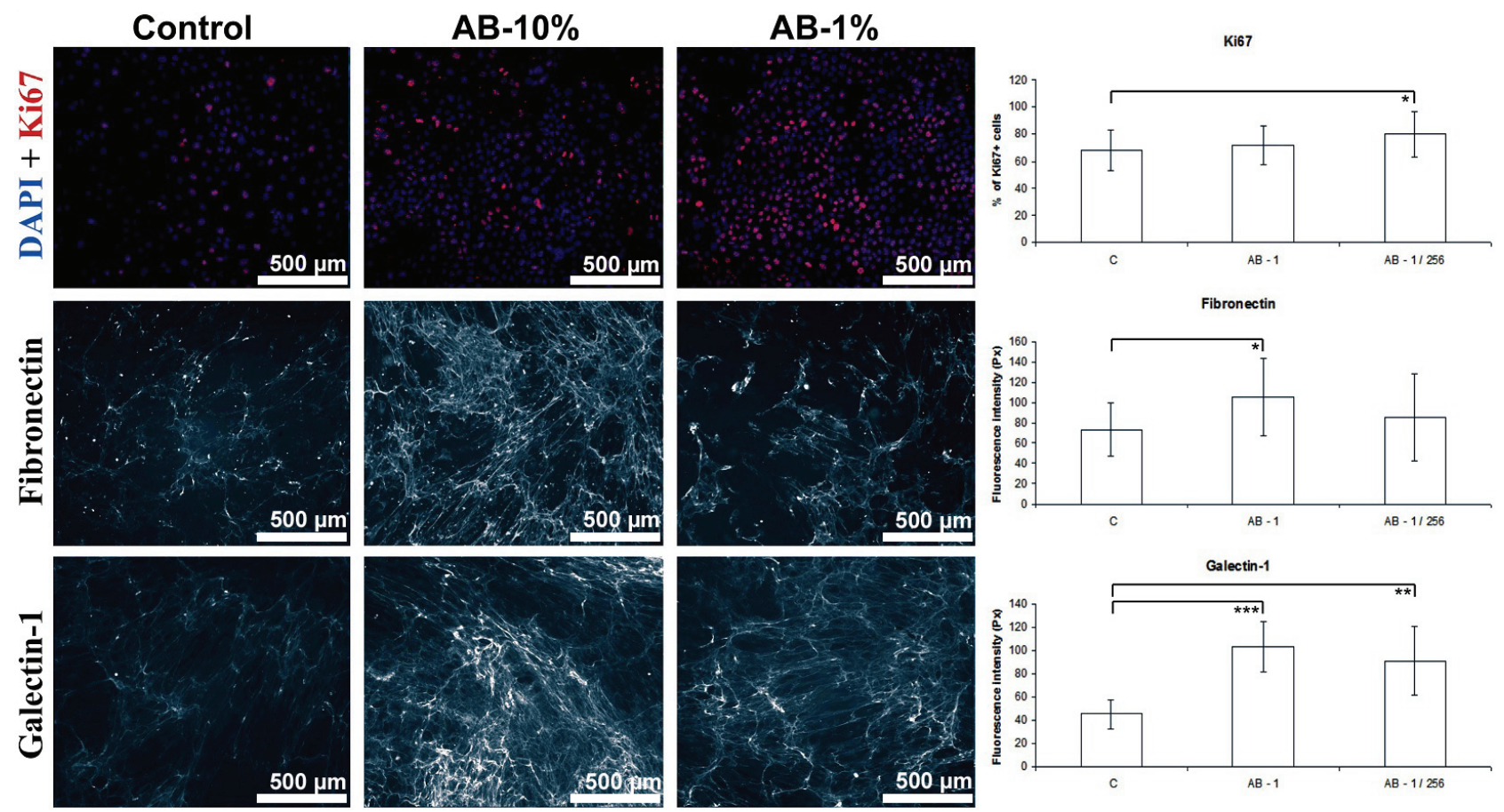

Fig. 3. Control cultures and cultures with cells exposed to two different concentrations of Atropa belladonna (AB); first horizontal panel: HaCaT keratinocytes with the largest population of Ki67-positive cells in cultures exposed to the lower tested AB concentration; second and third horizontal panels: human dermal fibroblast with the highest extent of ECM formation monitored by detection of fibronectin and galectin-1 in cultures exposed to the higher tested AB concentration; the percentage of Ki67-positive cells is shown in the top graph, fibronectin-dependent fluorescence intensity in the middle graph, and galectin-1-dependent fluorescence intensity in the bottom graph $(* \mathrm{p}<0.05, * * \mathrm{p}<0.01, * * * \mathrm{p}<0.001)$.

expressing keratin-19 in cultures which were supplemented with the highest tested concentration of $\mathrm{AB}$ (Gál et al. 2009). Such a cell phenotype is evocative of stem-like features (Dvořánková et al. 2005), implying a beneficial role for wound healing. In further study we have also shown that keratinocytes cultured on substratum, rich in fibronectin and galectin-1, induced by several galectins, have a poorly differentiated phenotype with keratin-19 expression (Dvořánková et al. 2011). In the current investigation, we used the HaCaT cell line and revealed that $\mathrm{AB}$ increases $\mathrm{Ki} 67$ expression, but did not affect keratin-19 expression. Obviously, previously observed keratin-19 expression may depend on 3T3 feeder fibroblasts which might be affected by AB. Along this line, it was found that wound treatment with Datura alba L. (Solanaceae) extract led to accelerated epidermis regeneration and increased fibroblast proliferation (Priya et al. 2002).

Following $\mathrm{AB}$ treatment we previously described increased wound tensile strength and presence of collagen in healing skin wounds (Gál et al. 2009). Formation and reorganization of the ECM are crucial processes involved in ensuring sufficient wound stiffness and successful healing. It is well known that fibronectin plays an important role herein. Fibroblasts as a component of granulation tissue secrete both proteases, which are able to proteolytically process surrounding ECM, and new constituents of the ECM including fibronectin and collagen that establish the insoluble matrix (Kumar et al. 2003). Therefore, we have monitored fibronectin production after cells and/or wounds were exposed to aqueous $\mathrm{AB}$ extract. We found that this treatment of wounds/cells enhanced fibronectin production. Of note, the effect of $\mathrm{AB}$ on collagen-3 expression revealed a concentration-dependent manner (AB-10\% decreased, whereas AB-1\% increased collagen deposition in wounds).

Interestingly, newly formed ECM was also rich in galectin-1. This lectin can directly affect cytokine production such as induced IL-10 secretion and decreased IFN- $\gamma$ production in activated T cells (Stowell et al. 2008) and is a potent effector in $\mathrm{T}$ cell communication (Wang et al. 2009) and its expression is elevated during the inflammatory phase of healing (Gál et al. 2011). In addition, pharmacological treatment with galectin-1 inhibited leukocyte recruitment into the peritoneal cavity (Gil et al. 2006). Reduction of the inflammatory process by means of lower number of infiltrated PMNLs, also 
seen for CD45-positive lymphocytes (Saussez et al. 2009), and scarce degranulated mast cells were observed when galectin-1 was administered locally (Rabinovich et al. 2000). Obviously, the lectin intimately partakes in the regulation of the inflammatory process (Schwartz-Albiez 2009). The results with experimentally applied galectin-1 or upon its in situ up-regulation in tumors can have relevant results for us, in which $\mathrm{AB}$ significantly reduced the process of inflammation (Gál et al. 2009), a process associated with increased production of galectin-1. Moreover, anti-inflammatory properties of $\mathrm{AB}$ were documented by significantly increased wound tensile strength in both treated groups just with unimpressive treatment duration differences (Gál et al. 2009). From this point of view, anti-inflammatory effects of $A B$ extract may engage enhanced generation of galectin-1.

Based on our previous (Gál et al. 2009) and current investigations we may conclude that the plant extract's effect is probably based on the acceleration of several processes occurring during wound healing. In particular, $\mathrm{AB}$ is able to stimulate ECM production, endothelial cells proliferation (as previously shown in HUVECs and may indicate accelerated angiogenesis), and has anti-inflammatory effects (as previously shown in rats). In our previous study, detectable concentrations of tropane alkaloids in water extract of leaves of Atropa belladonna L. were confirmed (Gál et al. 2009). Concentration of atropine has been more than ten times higher when compared to scopolamine. This is in accordance with results of Zárate et al. (1997) which found in leaves of Atropa beatica higher amount of atropine than scopolamine, with atropine/scopolamine ratio similar to results obtained in our previous study. Of note the pharmacological effect on wound healing may; however, be modulated either positively or negatively by other additional ballast compounds of the extract. Therefore, the main limitation of presented study is in omission of biological active compounds isolation following their wound healing effect evaluation. Accordingly, further research is needed to explain the underlying mechanisms of action and find optimal therapeutic concentration for any use in clinical practice. But the presented data indicate the potential for further study of this extract, also in defining the possible regulatory pathways.

\section{Conflict of Interest}

There is no conflict of interest.

\section{Acknowledgements}

We thank Magdaléna Majnušová, Iva Burdová, and Vít Hajdúch for their expert technical assistance. This study was supported by the Charles University in Prague (program for the Specific university research No. 264510), by the Ministry of Education, Science, Research and Sport of the Slovak Republic (VEGA No. $1 / 1095 / 11)$, by the Safarik University in Kosice (Institutional student Grants No. 5/GSŠ/2011, No. 6/GSŠ/2011, and No. VVGS-39/12-13), and by the EC Glyco-HIT consortium (No. 260600). These results were partially presented at the $4^{\text {th }}$ Young Biomedical Engineers and Researchers Conference - YBERC 2010, held in Košice (Slovak Republic) on July 1-3, 2010.

\section{References}

BOUKAMP P, PETRUSSEVSKA RT, BREITKREUTZ D, HORNUNG J, MARKHAM A, FUSENIG NE: Normal keratinization in a spontaneously immortalized aneuploid human keratinocyte cell line. J Cell Biol 106: 761$771,1988$.

CHEN M, PRZYBOROWSKI M, BERTHIAUME F: Stem cells for skin tissue engineering and wound healing. Crit Rev Biomed Eng 37: 399-421, 2009.

CHU Y, YU D, WANG P, XU J, LI D, DING M: Nanotechnology promotes the full-thickness diabetic wound healing effect of recombinant human epidermal growth factor in diabetic rats. Wound Repair Regen 18: 499-505, 2010.

COOPER D, ILARREGUI JM, PESOA SA, CROCI DO, PERRETTI M, RABINOVICH GA: Multiple functional targets of the immunoregulatory activity of galectin-1: control of immune cell trafficking, dendritic cell physiology, and T-cell fate. Methods Enzymol 480: 199-244, 2010.

DVOŘÁNKOVÁ B, SMETANA K Jr, CHOVANEC M, LACINA L, ŠTORK J, PLZÁKOVÁ Z, GALOVIČOVÁ M, GABIUS H-J: Transient expression of keratin 19 is induced in originally negative interfollicular epidermal cells by adhesion of suspended cells. Int J Mol Med 16: 525-531, 2005. 
DVOŘÁNKOVÁ B, SZABO P, LACINA L, GÁL P, UHROVA J, ZIMA T, KALTNER H, ANDRÉ S, GABIUS H-J, SYKOVÁ E, SMETANA K Jr: Human galectins induce conversion of dermal fibroblasts into myofibroblasts and production of extracellular matrix: potential application in tissue engineering and wound repair. Cells Tissues Organs 194: 469-480, 2011.

FU X, LI H: Mesenchymal stem cells and skin wound repair and regeneration: possibilities and questions. Cell Tissue Res 335: 317-321, 2009.

GABIUS H-J: Cell surface glycans: the why and how of their functionality as biochemical signals in lectin-mediated information transfer. Crit Rev Immunol 26: 43-80, 2006.

GABIUS H-J, ANDRÉ S, JIMÉNEZ-BARBERO J, ROMERO A, SOLÍS D: From lectin structure to functional glycomics: principles of the sugar code. Trends Biochem Sci: 36: 298-313, 2011.

GÁl P, TOPORCER T, GRENDEL T, VIDOVÁ Z, SMETANA K Jr, DVOŘÁNKOVÁ B, GÁL T, MOZEŠ S, LENHARDT L, LONGAUER F, SABOL M, SABO J, BAČKOR M: Effect of Atropa belladonna L. on skin wound healing: biomechanical and histological study in rats and in vitro study in keratinocytes, 3T3 fibroblasts, and human umbilical vein endothelial cells. Wound Repair Regen 17: 378-386, 2009.

GÁL P, NOVOTNÝ M, VASILENKO T, DEPTA F, ŠULLA I, TOMORI Z: Decrease in wound tensile strength following post-surgical estrogen replacement therapy in ovariectomized rats during the early phase of healing is mediated via ER- $\alpha$ rather than ER- $\beta$ : a preliminary report. $J$ Surg Res 159: e25-e28, 2010.

GÁl P, VASILENKO T, KOSTELNÍKOVÁ M, JAKUBČO J, KOVÁČ I, SABOL F, ANDRÉ S, KALTNER H, GABIUS HJ, SMETANA K Jr: Open wound healing in vivo: monitoring binding and presence of adhesion/growth-regulatory galectins in rat skin during the course of complete re-epithelialization. Acta Histochem Cytochem 44: 191-199, 2011.

GIL CD, COOPER D, ROSIGNOLI G, PERRETTI M, OLIANI SM: Inflammation-induced modulation of cellular galectin-1 and -3 expression in a model of rat peritonitis. Inflamm Res 55: 99-107, 2006.

GURDOL F, CIMSIT M, ONER-IYIDOGAN Y, KOCAK H, SENGUN S, YALCINKAYA-DEMIRSOZ S: Collagen synthesis, nitric oxide and asymmetric dimethylarginine in diabetic subjects undergoing hyperbaric oxygen therapy. Physiol Res 59: 423-429, 2010.

KALTNER H, SEYREK K, HECK A, SINOWATZ F, GABIUS HJ: Galectin-1 and galectin-3 in fetal development of bovine respiratory and digestive tracts. Comparison of cell type-specific expression profiles and subcellular localization. Cell Tissue Res 307: 35-46, 2002.

KLÍMA J, LACINA L, DVORÁNKOVÁ B, HERRMANN D, CARNWATH JW, NIEMANN H, KALTNER H, ANDRÉ S, MOTLÍK J, GABIUS HJ, SMETANA $\mathrm{K}$ Jr: Differential regulation of galectin expression/reactivity during wound healing in porcine skin and in cultures of epidermal cells with functional impact on migration. Physiol Res 58: 873-884, 2009.

KUMAR V, COTRAN RZ, ROBBINS SL: Basic Pathology. $7^{\text {th }}$ Ed. Saunders, Philadelphia, 2003, 873 pp.

LACJAKOVÁ K, BOBROV N, POLÁKOVÁ M, SLEZÁK M, VIDOVÁ M, VASILENKO T, NOVOTNÝ M, LONGAUER F, LENHARDT L, BOBER J, LEVKUT M, SABOL F, GÁL P: Effects of equal daily doses delivered by different power densities of low-level laser therapy at $670 \mathrm{~nm}$ on open skin wound healing in normal and corticosteroid-treated rats: a brief report. Lasers Med Sci 25: 761-766, 2010.

LAU K, PAUS R, TIEDE S, DAY P, BAYAT A: Exploring the role of stem cells in cutaneous wound healing. Exp Dermatol 18: 921-933, 2009.

LUO G, CHENG W, HE W, WANG X, TAN J, FITZGERALD M, LI X, WU J: Promotion of cutaneous wound healing by local application of mesenchymal stem cells derived from human umbilical cord blood. Wound Repair Regen 18: 506-513, 2010.

MICHEL M, TÖRÖK N, GODBOUT MJ, LUSSIER M, GAUDREAU P, ROYAL A, GERMAIN L: Keratin 19 as a biochemical marker of skin stem cells in vivo and in vitro: keratin 19 expressing cells are differentially localized in function of anatomic sites, and their number varies with donor age and culture stage. $J$ Cell Sci 109: 1017-1028, 1996. 
NEČAS A, PLÁNKA L, SRNEC R, CRHA M, HLUCILOVÁ J, KLÍMA J, STARÝ D, KREN L, AMLER E, VOJTOVÁ L, JANCÁR J, GÁL P: Quality of newly formed cartilaginous tissue in defects of articular surface after transplantation of mesenchymal stem cells in a composite scaffold based on collagen I with chitosan micro- and nanofibres. Physiol Res 59: 605-614, 2010.

NICKE B, DETJEN K., LOGSDON CD: Muscarinic cholinergic receptors activate both inhibitory and stimulatory growth mechanisms in NIH3T3 cells. J Biol Chem 274: 21701-21706, 1999.

NISHINO Y, YAMADA Y, EBISAWA K, NAKAMURA S, OKABE K, UMEMURA E, HARA K, UEDA M: Stem cells from human exfoliated deciduous teeth (SHED) enhance wound healing and the possibility of novel cell therapy. Cytotherapy 13: 598-605, 2011.

NOVOTNÝ M, VASILENKO T, VARINSKÁ L, SMETANA K Jr, SZABO P, SARIŠSKÝ M, DVOŘÁNKOVÁ B, MOJŽIŠ J, BOBROV N, TOPORCEROVÁ S, SABOL F, MATTHEWS BJ, GÁL P: ER- $\alpha$ agonist induces conversion of fibroblasts into myofibroblasts, while ER- $\beta$ agonist increases ECM production and wound tensile strength of healing skin wounds in ovariectomised rats. Exp Dermatol 20: 703-708, 2011.

PRIYA KS, GNANAMANI A, RADHAKRISHNAN N, BABU M: Healing potential of Datura alba on burn wounds in albino rats. J Ethnopharmacol 83: 193-199, 2002.

PRIYA KS, ARUMUGAM G, RATHINAM B, WELLS A, BABU M: Celosia argentea Linn. leaf extract improves wound healing in a rat burn wound model. Wound Repair Regen 12: 618-625, 2004.

RABINOVICH GA, SOTOMAYOR CE, RIERA CM, BIANCO I, CORREA SG: Evidence of a role for galectin-1 in acute inflammation. Eur J Immunol 30: 1331-1339, 2000.

SAAL I, NAGY N, LENSCH M, LOHR M, MANNING JC, DECAESTECKER C, ANDRÉ S, KISS R, SALMON I, GABIUS HJ: Human galectin-2:expression profiling by RT-PCR/immunohistochemistry and its introduction as histochemical tool for ligand localization. Histol Histopathol 20: 1191-1208, 2005.

SAUSSEZ S, DECAESTECKER C, CLUDTS S, ERNOUX P, CHEVALIER D, SMETANA K Jr, ANDRE S, LEROY X, GABIUS HJ: Adhesion/growth-regulatory tissue lectin galectin-1 in relation to angiogenesis/lymphocyte infiltration and prognostic relevance of stromal up-regulation in laryngeal carcinomas. Anticancer Res 29: 59-65, 2009.

SCHWARTZ-ALBIEZ R: Inflammation and glycosciences. In: The Sugar Code Fundamentals of Glycosciences. GABIUS H-J (ed), Wiley-VCH, Weinheim, 2009, pp 447-467.

SKÓRKOWSKA-TELICHOWSKA K, ZUK M, KULMA A, BUGAJSKA-PRUSAK A, RATAJCZAK K, GASIOROWSKI K, KOSTYN K, SZOPA J: New dressing materials derived from transgenic flax products to treat long-standing venous ulcers--a pilot study. Wound Repair Regen 18: 168-179, 2010.

STOWELL SR, QIAN Y, KARMAKAR S, KOYAMA NS, DIAS-BARUFFI M, LEFFLER H, MCEVER RP, CUMMINGS RD: Differential roles of galectin-1 and galectin-3 in regulating leukocyte viability and cytokine secretion. J Immunol 180: 3091-3102, 2008.

SUZUKI K, SAITO J, YANAI R, YAMADA N, CHIKAMA T, SEKI K, NISHIDA T: Cell-matrix and cell-cell interactions during corneal epithelial wound healing. Prog Retin Eye Res 22: 113-133, 2003.

TOPORCER T, RADONÁK J: Vacuum assisted wound closure - overview of lesson and applications. (in Slovak) Čas Lék Česk 145: 702-707, 2006.

VASILENKO T, SLEZÁK M, KOVÁC I, BOTTKOVÁ Z, JAKUBCO J, KOSTELNÍKOVÁ M, TOMORI Z, GÁL P: The effect of equal daily dose achieved by different power densities of low-level laser therapy at 635 and $670 \mathrm{~nm}$ on wound tensile strength in rats: a short report. Photomed Laser Surg 28: 281-283, 2010.

VILLALOBO A, NOGALES-GONZALÉS A, GABIUS H-J: A guide to signaling pathways connecting protein-glycan interaction with the emerging versatile effector functionality of mammalian lectins. Trends Glycosci Glycotechnol 18: 1-37, 2006.

WANG J, LU ZH, GABIUS H-J, ROHOWSKY-KOCHAN C, LEDEEN RW, WU G: Cross-linking of GM1 ganglioside by galectin-1 mediates regulatory T cell activity involving TRPC5 channel activation: possible role in suppressing experimental autoimmune encephalomyelitis. J Immunol 182: 4036-4045, 2009.

ZÉRATE R, HERMOSIN B, CANTOS M, TRONCOSO A: Tropane alkaloid distribution in Atropa beatica plants. J Chem Ecol 23: 2059-2066, 1997. 